\title{
Calvin's instruction on the fifth commandment
}

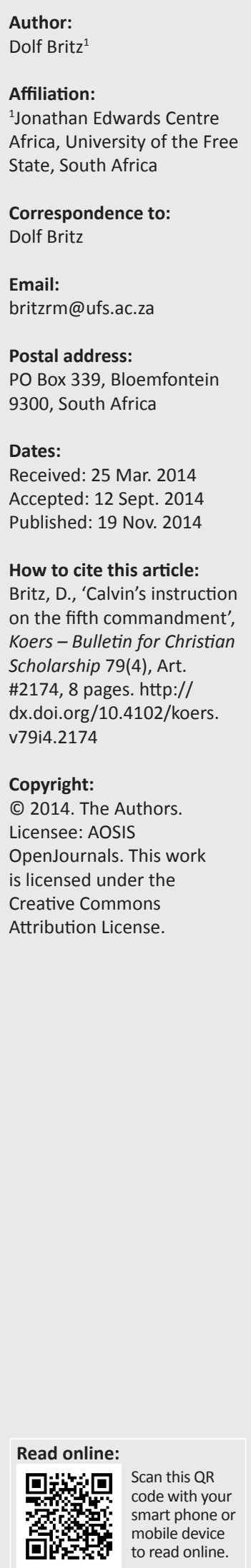

In this article Calvin's explication of the fifth commandment in his works intended to be used in education and catechetical instruction is surveyed. The investigation is restricted to (in this sequence) the 1536 Institutio, the Instruction et Confession de Foy, printed in Geneva in 1537 and 1538, l'Institution puerile de la doctrine Chrestienne and the expanded Institutio (1539) and incorporated Calvin's exposition of the core biblical texts (Ephesians, Colossians, Exodus and Deuteronomy) used for his explanation of the fifth commandment. The renowned Catechismus $(1541 / 1545)$ is then scrutinised, followed by a consideration of La maniere d'interroguer les enfans qu'on veut recevoir a la cene Seigneur Iesus Christ (1553). The aim of the research is not limited to a discussion of the content of Calvin's exposition, but also to establish whether a development can be traced in the theological thinking of Calvin. The conclusion is that Calvin supplemented and clothed the basic trajectories of his interpretation, but that the 1539 Institutio provided the most complete and finalised explication of the fifth commandment. In addition, the conditional obedience of children is omitted in the 1545 Catechismus. It was probably done for pedagogical reasons.

Calvyn se onderrig oor die vyfde gebod. Hierdie artikel gaan Calvyn se uitleg van die vyfde gebod in sy werke na wat op onderrig, insluitende die kategese, gemik was. Agtereenvolgens is die 1536 Institutio, die Instruction et Confession de Foy, gedruk in Genève in 1537 en 1538, l'Institution puerile de la doctrine Chrestienne en die uitgebreide Institutio (1539) ontleed. Hierna word die beroemde Catechismus (1541/1545) onder die loep geneem. Die oorweging van La maniere d'interroguer les enfans qu'on veut recevoir a la cene Seigneur Iesus Christ (1553) voltooi die navorsing. Die vraag aan hierdie werke van Calvyn is nie beperk tot die inhoud van Calvyn se uitleg nie, maar ook of daar 'n teologiese ontwikkeling af te lees is. Die gevolgtrekking is dat Calvyn die basiese trajekte van sy uitleg aangevul en ingeklee het, maar dat die 1539 Institutio die mees volledige en gefinaliseerde uitleg bevat. Hierbenewens het Calvyn in die uitgewerkte Catechismus nie alles wat byvoorbeeld in die 1539 Institutio (en ook sy kommentare op Eksodus, Deuteronomium, Efesiërs en Kolossense) na vore gebring is, ingesluit nie. Dit was waarskynlik om pedagogiese redes gedoen.

\section{Introduction}

The Ten Commandments undeniably played a key role in Calvin's teaching and theology. He used and explained the commandments not only to inform and order the practice of the Christian life, connecting it to the redemptive work of Christ, but also to shape the public arena. For this reason he has elucidated the Decalogue in detail, in particular in the publications that were aimed at education, such as his Institutes of the Christian Religion (De Greef 1989:179-185; Selderhuis 2008:232-239) and the catechetical booklets and writings (De Greef 1989:122-123; Selderhuis 2008:239-248) he set up for the instruction of the children of the congregation. This article traces Calvin's interpretation of the fifth commandment in these writings. How did he understand - as he called it - this 'supreme or absolute rule of all justice', this 'ordinance of God'? How did he interpret the honour to be rendered to father and mother? Did he reflect critically on the blessing of a long life embedded in obedience to parents? If these writings are considered in chronological order (as is the intention of this contribution), an additional question is whether a development in Calvin's thinking on the exposition of the fifth commandment can be identified between 1536 and 1553, the date that marked the first appearance of the last catechism booklet.

The investigation commences with Calvin's writings published in the mid-1530s: the first edition of the (Basle) Institutio (1536) and the Instruction et Confession de Foy printed in Geneva in 1537 and 1538. The Instruction served as a core document to enhance the reformation of the city. The attention then shifts to Calvin's work and ministry in Strasbourg (1538-1541). Here he compiled 
l'Institution puerile de la doctrine Chrestienne ${ }^{1}$ and also reviewed the Institutio (1539), in which was incorporated an extensive exposition of the fifth commandment. Back in Geneva (since 1541), he wrote and published the Catechismus $(1541 / 45)$ that quickly gained international status and circulation. Then followed in the early 1550 s a short learning book, designed for children who signed up for admission to and participation in the Lord's Supper. The consideration of La maniere d'interroguer les enfans qu'on veut recevoir a la cene Seigneur Iesus Christ (1553) thus concludes the research. The outcome is summarised in the final conclusion, aiming at profiling the trajectories of Calvin's thought on the fifth commandment.

\section{The first explication of the fifth commandment: 1536-1538}

To the best of my knowledge, Calvin for the first time deliberately offered an explication of the fifth commandment in the 1536 Christianae Religionis Institutio (OS I), which he treats in chapter one: De lege, quod decalogi explicationem continet. It is nothing more than a concise explanation, following the biblical text. Because we must fear and love God, Calvin writes, we should not hold our parents in contempt nor offend (or aggravate) them. Rather, according to the will of God, and with reference to Ephesians 6:1-3 and Matthew 15:4-6, we should treat them with honour and obedience and serve them with gratitude. The Lord promises such children a blessed life on earth; but, to the contrary, he underlines, an inevitable curse should be expected by ungrateful children who neglect to display love and gratitude towards their parents (OS I, 49.21-35).

In his Instruction et Confession de Foy dons on use en leglise de Geneve (OS I, 378-417; CO 22, 33-74; Calvin StA 1/1, 138ff.; Saxer 1994:131ff.; COR III/II:XI-XXIII), published in $1537 / 1538$, Calvin observes in the introduction to the exposition of the law that in the law of God we are given 'une tresparfaicte reilgle de toute iustice' (OS I,383; Calvin StA 1/1, 146.11-12: 'a supreme/absolute rule of all justice'). In his exposition of the fifth commandment here, thus for the second time, the 1536 domestic structure (parents-children, honour-obedience, gratitude-care/service, transgressioncurse) is maintained (OS I, 386; Calvin StA 1/1, 152.15-35). However, he now (in Geneva) adds new insights that significantly expanded the range of understanding the text. In this command, he continues, we are compelled to exercise devotion (or loyalty) (la piete) towards our fathers and mothers, as well as to those, he now adds, who are in the same degree in authority over us, such as princes and magistrates. They must be afforded the highest obedience, gratitude and reverence, and served to the best of our ability (Calvin StA 1/1,152.19-20). ${ }^{2}$

1.The date of publication is uncertain, but it was certainly published between 1538 and 1541.

2.... cest a scavoir que nous leur facoins toute reverence obieissance et recognoissancem et tous les services quil nous est possible ... (Calvin StA 1/1 152.19-20).
He then directs his attention at elaborating on the correlation of parents and children as indicated by this commandment. It is according to the will of the Lord that mutual service be accorded to those who have brought us into life, he asserts. Whether they are worthy to be held in this honour or not, Calvin continues, makes no difference. They have been set as parents by the Lord, who has willed children to honour them. He gave them as fathers and mothers (Calvin StA 1/1, 152.22-25). But, it must also be noted, Calvin significantly observes, that we are not commanded to obey them in any other way (differently) than in God (en Dieu), as Paul indicated in Ephesians 6:1. Accordingly, children may not contravene the commandment to satisfy them (father and mother) in any way. Indeed, if parents should demand of them anything that is directed against God, children should no longer regard them as father and mother, but rather as strangers who want to put an end to their obedience to 'our true Father' (Calvin StA 1/1, 152.26-30, OS I, 386.33-38). ${ }^{3}$

Finally, Calvin refers to Ephesians 6:2. According to Paul, this is the first commandment with a promise, he says. The Lord promises the blessing of the present life to children who revere their parents with fitting observance, but at the same time directs his curse over all children who are rebellious and disobedient (Calvin StA 1/1, 152.30-35).

Comparing the 1536 and $1537 / 1538$ explications of the fifth commandment, the similarities as well as the expansion of the scope of the commandment, argued in the 1537/1538 Instruction, are apparent. In the Instruction et Confession Calvin is explicit: Not only parents, but also those who are in the same degree in authority over us, such as princes and magistrates, must be shown the highest obedience, gratitude and reverence. Calvin's statement that if parents should demand of children anything that is directed against God, the children should no longer regard them as father and mother, but rather as strangers who want to put an end to their obedience to their true Father, constitutes a second line of thinking, added now to the explanation of the commandment. As a line of thinking conditional obedience is a well-known (and thoroughly studied) Calvinistic notion, related to his teaching on obedience/ disobedience to authorities and the state. In the 1537-1538 explanation, however, Calvin applies it to the familial framework: parents are to be obeyed conditionally, and not unconditionally (as argued in the 1536 Institutio). Obedience to God overshadows obedience to parents (and authorities), even though He provided them. This obedience must be en Dieu, in God.

If we accept that the Instruction was intended rather for parents to teach their children, and not for children per se, the immediate question is whether Calvin hereby did justice to Scripture? Even if we consider that in Geneva at that time

3.Pourtant il ne fault pas pour leur complaire transgresser la Loy du Seigneur, car silz nous commandment rien contre Dieu en ce nous ne les devons pas reputer pour pere et mere, mais comme estrangiers, lesqualz nous veullent retirer de lobeissance de nostre vray Pere (Calvin StA 1/1, 152.26-30). 
(1537) there was still much left of the Roman Catholic past with its entitlements, demands, loyalties, traditions and superstitions that contravened and undermined the Genevan reformation, the question persists whether his remark does not allow room for the possibility of an unbiblical relentless tension between children and parents. Does he offer children an opportunity that they could abuse? And did he sustain this conditional obedience required of children in subsequent writings and publications dealing with the fifth commandment? Or was he motivated by protecting the honour of God?

In 1538 Calvin had to leave Geneva. He found refuge in Strasbourg, where he worked with Bucer and enjoyed his ministry to the French congregation in the city. For this congregation he compiled l'Institution puerile de la doctrine Chrestienne. He also thoroughly reviewed his Institutio. In both these writings the Decalogue was elucidated again. To these publications our attention must now be turned.

\section{Explications in Strasbourg: 1539-1541}

In Strasbourg l'Institution puerile de la doctrine Chrestienne faicte par maniere de dialogue (OS II,152-157), used in the French congregation and later in Geneva, was written and published between 1538 and 1541 (De Greef 1989:122). In this booklet Calvin offers a concise explanation of the commandment (OS II, 156.38-157.1). Children should honour, serve and obey not only their parents, but also the magistrate and their tutors (OS II, 156.41), ${ }^{4}$ as well as all those that are in (senior) civil positions of authority (OS II, 156.41). ${ }^{5}$ The child is expected to exercise himself/herself in this, because in doing so he/she will learn to live well and God will give him/her a long and peaceful life. Tutors are added to the list of those who should be obeyed, and no mention is made of any conditions that are to be met in this regard.

In reworking and enlarging the 1536 Institutio, Calvin argued a substantial elaborated exposition of the law in what he now titled the Institutio Christianae Religionis, published in Strasbourg in 1539 (OS III, 376ff.). The explication of the fifth commandment - for the fourth time in as many years - receives four paragraphs, covering the purpose (OS III, 376.28ff.), the demand (OS III, 377.26ff.), the promise (OS III, 378.12ff.) and the threat (OS III, 379.3ff.). In his explicatio Calvin keeps to his line of thinking as put forth in the first edition (1536) and in particular in the Instruction et Confession (1537/1538). He incorporates at least two additional trajectories, though, in his view relevant to an appropriate and argued comprehension of the commandment.

Ultimately, Calvin comments, the meaning of the commandment is that we should look up to those whom

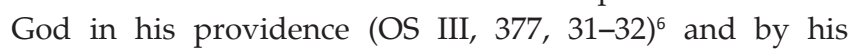

4.... a mes precepteurs (OS II, 156.41).

5.... et a tous ceux a qui ie suis commis (OS II, 156.41).

6.... non tamen sine Dei providentias hunc locum assecuti sunt ... (OS III, 377.31-32). ordinance (OS III, 377.26) $)^{7}$ has placed over us. We should respect them with honour and reverence, obedience, and gratitude (OS III, 376.30-32). ${ }^{8}$ It follows from this that we are forbidden to detract from their dignity either by contempt, by stubbornness or by ingratitude (OS III, 376.32-377.2). He is aware that the precept of subjection strongly conflicts with the depravity of human nature (OS III, 377.7)..$^{9}$ Thus, Calvin says, God has provided that kind of superiority, which is by nature most amiable and least invidious, to soften and bend our minds and to gradually accustom us to lawful subjection which can be tolerated (OS III, 377.9-12). ${ }^{10}$ Obviously he has submission to parents in mind - submission being theologically motivated (OS III, 377.2-24; 378.12ff.). The titles Father, God and Lord belong to God, but he shares these titles with persons in which he thus lights up a spark of his splendour. Fathers, princes and lords have thus some share in God's honour and should therefore be honoured (OS III, 377.21-22). ${ }^{11}$ In so doing, God has established a universal rule (OS III, 377.24-25). ${ }^{12}$ It does not make any difference, therefore, whether superiors are worthy or unworthy of this honour - they have attained their position through God's providence.

God, however, explicitly commands children to revere their parents. In a way, Nature itself ought to teach man this, Calvin asserts, because those who abusively and stubbornly violate parental authority are monsters, not humans (OS III, 377.34), ${ }^{13}$ and thus subjected to just punishment. This is the reason why the Lord had commanded that all those disobedient to their parents be put to death, according to important additions to the law in the Old Testament. In Exodus 21:17, Leviticus 20:9 and Proverbs 20:20 the Lord confirms reverence when he enjoins that one who curses (i.e. the opposite of reverence) his father or mother should be killed. God thus punishes contempt and abuse (OS III, 377.37-378.4). In Deuteronomy 21:18-21 God, in confirming obedience, decrees the penalty of death for disobedient and rebellious children (OS III, 378.5-7). This is a new line of thinking in the explanation of the fifth commandment. It surfaced for the first time thus in the 1539 Institutio.

The third kind of honour - gratitude - Calvin finds in what Christ said concerning the contemporary interpretation of the commandments - that we should do good to our parents

7.... eius ordinatione (OS Iil, 377.26 ).

8.Summa igitur erit ut quos nobis preafecit Dominus, eos suspiciamus, eosque et honore et obientia et gratitudine honoremus (OS III, 376.30-32). See also ... tres esse honoris de quo hic loquitur partes, reverentiam, obidientiam, gratitudiam (OS III, 378.2-3).

9.... cum humani ingenii pravitate valde pugnat ... (OS III, 377.7).

10.Ad omnem ergo legitimam subiectionem ab ea quae facillima est tolerate ... (OS III, 377.12-13).

11.Ita qui nobis est pater, in eo divinum aliquid reputare par est, quia divinum titulum non sine causa gerit (OS III, 377.21-22). In him who is our father, we should therefore recognise something divine, because he does not bear the divine title without reason.

12.Quapropter ambiguum esse non debet quin hic universalem regulam Dominus statuat ... (OS III, 377.24-25)

13.Monstra enim sunt, non homines ... (OS III, 377.34). 
- in Matthew 15:4-6, and what Paul emphasises in Ephesians 6:1-3 and Colossians 3:20 (OS III, 378.7-11).

The promise is added as a recommendation, as Paul confirms in Ephesians 6. This is to underpin how pleasing this kind of submission is to God (OS III, 378.12-14). Calvin again explains the difference between Israel (possession of the land Canaan) and believers in Christ (the whole earth). Therefore the meaning is: honour your father and mother so that through a long life you may enjoy the possession of the land, which is to be yours as a testimony to my grace (OS III, 378.23-26). ${ }^{14}$ At this point, Calvin, in his teaching, is aware of the fact that the promise could be elevated to meet unlimited material expectations and application, and thus could raise serious questioning of the providence of God, should the opposite be true. In addressing the issue, he takes account, for example, of the fact that unexpected death often terminates the lives of obedient young people, which does not, he argues, bring the promise into jeopardy (OS III, 378.32ff.) The whole point here, Calvin says, is that we should reflect that we are promised a long life in so far as it is a blessing of God; and that it is a blessing only in so far as it is evidence of God's favour, which he testifies to his servants far more richly and substantially through death, and proves it in reality (OS III, 378.37-379.2). These observations constitute a second new line of thought, added to his understanding of the commandment.

The commandment also carries an implicit threat: an inevitable curse threatens all stubborn and disobedient children (OS III, 379.5-6). ${ }^{15}$ To assure that the commandment is carried out, Calvin indicates that God has declared contempt and abuse subject to punishment and even to the sentence of death (OS III, 379.6-16). Calvin notes in conclusion that we are bidden to obey our parents only 'in the Lord' (Eph 6:1ff.; OS III, 379.16ff.). This is apparent from the principle already laid down, he writes. For they sit in that place to which they have been advanced by the Lord, who shares with them a part of his honour, he explains. Therefore, the submission paid to parents ought to be a step towards honouring that highest Father. Hence, if they spur us to transgress the law, we have a perfect right to regard them not as parents, but as strangers who are trying to lead us away from obedience to our true Father. In the same way we should, he adds, act towards princes, lords, and every kind of superior (OS III, 379.21-24). ${ }^{16}$

The exposition in the 1539 Institutio encompasses a much broader look at the meaning of the fifth commandment, as was offered in the preceding published works. It should also be seen as conclusive. In all the subsequent editions of the Institutio Calvin did not alter or review his explanation of

14.. Sensus ergo est, Honora patrem et matrem, qua per longum vitae spatium frui tibi diu liceat ea terrae possesione quae tibi future est in gratiae meae testimonium (OS III, 378.23-26).

15.... simul innuit, omnibus immorigeris ac inobsequentibus certissimam imminere maledictionem ... (OS III,379.5-6).

16.Quare si in Legis transgressionem nos instigant, merito tum non parentes nobis habendi sunt, sed extranei, qui nos a veri Patris obedientai subducere conantu (OS III, 379.2-24). the fifth commandment, nor did he elaborate on aspects of his interpretation. His interpretation of the commandment is firmly embedded in two sets of biblical texts. On the one hand, the New Testament's Ephesians 6:1-3 and Colossians 3:20-21 play a major role; on the other hand, Exodus 20:12 and Deuteronomy 5:16 form the core of the Old Testament texts Calvin used.

Except for Romans in 1539, Calvin commenced publishing his commentaries in 1548. The commentaries on Ephesians, Colossians and Exodus or Deuteronomy thus appeared after the publication of the 1539 Institutio. A condensed survey of Calvin's commentary on these texts is appropriate.

\section{Calvin's commentary on the fifth commandment}

As indicated above, reference to Ephesians (6:1ff.) and Colossians (3:20-21) repeatedly surfaces in Calvin's explication of the fifth commandment. How did he explain these verses in the 1548 Ioannis Calvini Commentarii, in quatuor Paulini Epistolas: ad Galatas, ad Ephesios, ad Philippenses, ad Colossenses, published in Geneva? A close reading of the commentary on the verses referred to reveals the familiar trajectories argued in his catechetical instructions and Institutio. Consistent with earlier publications discussed are Calvin's comments concerning Ephesians 6:1: the obedience of children is enforced by the authority of God. God has commanded it. His will is the unerring rule of righteousness and sincerity. The precept honour comprehends all the duties by which the sincere affection and respect of children to their parents can be expressed (CO 51, 227).

The exposition of Ephesians 6:2 and 3 (CO 51, 227) is also aligned to his views as expressed in the Institutio. The promise is to impart a greater cheerfulness to obedience. Calvin writes that Paul uses this as a kind of seasoning to render the submission, which he enjoins on children, more pleasant and agreeable. The promise is a long life among the gifts of God. Those who show kindness to their parents from whom they derived life are assured by God that in this life it will be well with them. The divine blessing is extended to the whole world and will last until the coming of Christ.

In the commentary on Ephesians 6:1 Calvin only hints at the notion of conditional obedience. Obedience of children towards parents is by the authority of God; therefore, Calvin states, parents are to be obeyed, so far only as is consistent with piety to God, which comes first in order (CO 51, 228). ${ }^{17}$ The performance of this duty cannot lead away from God Himself, Calvin writes.

Calvin is even more reserved and careful in the 1548 commentary on Colossians 3:20 and 21 (CO 52, 126.12ff.). According to him, Paul inculcates in children obedience to parents without reservation, in all things. But, he then asks,

17.Inde tamen sequitur, eatenus obediendum ess parentibus, ne laedatur erga Deum pietas, quae primum gradum obtinet (CO 51,228) 
what if parents impose on them something unlawful? Will they in this case also have to obey without reservation? (CO 52, 126.13ff.). ${ }^{18}$ Calvin is clear: the authority of men should not prevail at the expense of neglecting God. Obedience should always be in the Lord (Eph. 6:1). Calvin stresses that it is to make clear that obedience must be rendered not merely to just commands, but also to such as are unreasonable. Children should consider that whoever their parents may be, they have been allotted to them by the providence of God (CO 52, 126.24-27). By this appointment God makes children subject to their parents in all things. Therefore, they may not refuse anything, however difficult or disagreeable; in things indifferent they may give deference to the station which their parents occupy and that they may not put themselves on a footing of equality with their parents, in the way of questioning and debating, or disputing - it being always understood that conscience is not to be infringed upon (CO 52,126.30-32). ${ }^{19}$

Near the end of Calvin's life Mosis Libri V cum Ioannis Calvini Commentariis. Genesis seorsum: reliqui quatuor in formam harmoniae digesti was printed in Geneva in 1563 (CO 24; CO 25, 1-416). Obviously Calvin's commentary on Exodus 20:12 and Deuteronomy 5:16 should be considered as the core texts reflecting his understanding of the fifth commandment (CO 24, 602ff.). Human society, he observes, cannot be maintained in its integrity unless children modestly submit themselves to their parents, and unless those who are set over others by God's ordinance ${ }^{20}$ are even reverently honoured (CO 24, 602.39-603.1). ${ }^{21}$ The duties of piety towards parents include that they should regard them with reverence, obediently comply with their commands, heartily devote themselves to them and their services (CO 24, 603.22ff.) and take care of their parents (CO 24, 604.17).22 These include relieving poverty and aiding parents in need (CO 24, 604.23-24).

Calvin deals with three issues: unworthy parents, the blessing of a long life in the midst of miseries and afflictions (OC 24, 604.22ff.), and the rights of parents.

Should the objection be raised that ungodly and wicked fathers, who cannot be regarded and served with honour, Calvin replies that the perpetual law of nature is not subverted by the sins of men, and therefore, however unworthy of honour a father may be, he still retains his right over his children, provided it does not in any way derogate from the judgement of God (CO 24, 603.30-37ff.). ${ }^{23}$ Parents,

18.Sed quid si parentes ad illicitum quidpiam adigere eos velint: an sine discrimine etiam tunc parebunt? (CO 52, 126.13ff.).

19.... per Omnia, ut sibi inquirendo ac disceptando, vel altercando aequum ius non sumant. Semper tamen usque ad aras (CO 52,126.30-32).

20.These incorporate the judges of people, executing justice. See Deuteronomy 16:18 and 20:9.

21.Imo non aliter foveri et integra manere potst humana societas, quam si filii parentibus se modeste subiiciant, ac reventer etiam colantur quicunque aliis divinitus sunt praefecti (CO 24, 602.39-603.1).

22.Ut filii parentum curam gerant ( $\mathrm{CO} 24,604.17)$.

23.Si quis obiicat multos esse impios et sceleratos patres, de quibus honorifice sentire nequeunt filii quin tollant boni et mali discrimen: responsio in prompt est sentire nequeunt filii quin tollant boni et mali discrimen: responsio in prompt est,
hominum vitiis non tolli perpetuam naturae legem: ideoque quamlibet honore hominum vitiis non tolli perpetuam naturae legem: ideoque quamlibet honore
indignus sit pater, retinere tamen (quatenus pater est) ius suum in filios, modo ne id Dei iudicioquidquam derogate: ... (CO 24, 603.30-37ff.). he continues, govern their children only under the supreme authority of God. Obedience is restricted by Paul's indication that it should be 'in the Lord': if parents enjoin anything unrighteous, as an infringement of God's right, obedience is freely to be denied (CO 24, 604.2-3). ${ }^{24}$

The promise added to the commandment as a stimulus prompts the question as to its integrity, since earthly life is exposed to so many cares, pains, miseries and afflictions (CO 24, 604.40ff.). ${ }^{25}$ These, Calvin affirms, do not destroy the chief blessing of life as it is embodied in being preserved unto the hope of eternal inheritance by the Father, taking care of them (CO 24, 604.43ff.).

Calvin links the rights and entitlements of parents provided and guaranteed by the fifth commandment, to the violation of the commandment by children and the resultant punishment that includes the possibility of death sentence, as stipulated in Leviticus 20:9 and Deuteronomy 21:18-21 (CO 24, 607ff.). In sum, Calvin says, Moses declares that those are deserving death who are of such stubborn and intractable disposition as to reject the authority of their father and mother, and to hold them in contempt (CO 24, 608.3-6). God, though, requires the case to be decided on the evidence of father and mother and commands that it be heard publicly so that none may be condemned at the will of private individuals. Children therefore have to be brought before a tribunal of judges and legal matter thus undoubtedly ensues (CO 24, 608.27-30). In this trail, children should therefore be heard defending themselves, so as to clear themselves of the crime. At the very least, it is not to be decided in an arbitrary way (CO 24, 608.11ff.).

There is no contradiction between Calvin's teaching (in the Institutio and instructions) and the biblical commentaries. The commentaries provide a supplementary view that deepens and broadens the argument in the teaching of Calvin.

After this excursion, we have to return to the main focus of the article, which is to trace Calvin's exposition of the fifth commandment in works that were intended for teaching. In 1541 Calvin's life and ministry were about to change again: he was called back to Geneva, where he produced an outstanding and internationally used Catechismus. In this Catechismus the fifth commandment was again explained to the children of the congregation.

\section{Calvin's catechetical work in Geneva: 1542-1553}

On his return to Geneva, Calvin in 1541 offered the city and its church Le Catéchisme de l'Eclise de Genève, c'est a dire le Formulaire d'instruire les enfants en la Chrestiente (CO 6, 1-134; De Greef 1989:122), which was translated in Latin and published in 1545 as Catechismus ecclesiae genevensis, hoc est,

24... quo significant si quid iniuste pater iniungat, obsequium libere negandum esse (CO 24, 604.2-3)

25.... doloribus et molestiis obnoxia sit terran vita (CO 24, 604.40ff.). 
formula erudiendi pueris in doctrina Christi (OS II, 72-15; for the French text's questions and answers, see CO 6, 67 and 69). Calvin's exposition of the fifth commandment, unpacked in 11 questions and answers, in his renowned Catechismus, evidently requires careful consideration. Obviously the Catechismus was intended to teach children. What did Calvin ask, and how did he answer the questions in reference to this command? Did the trajectories which he had employed in the explication of the fifth commandment thus far emerge again in this Catechismus's teaching?

The main point in the questions and answers is that children must be, with modesty and humility, respectful and obedient to parents, serving them reverentially, helping them in necessity, and exercising their labour for them (OS I, 104.24ff. Question and answer 186). Secondly, Calvin focuses on the promise that is added to the commandment. By the blessing and mercy of God a long life will be given on earth to those who pay due honour to parents (OS I, 105.3-5. Question and answer 187). Calvin does not hesitate to raise an existential question (which is a reflection of the context in which he worked), that children, especially those living in paucity, would ask: Why does God promise us a long life aligned with his blessing if life is so full of miseries? (OS I, 105.8-12. Question and answer 189). Calvin answers that, even though our lives should be exposed to great miseries, yet there God's blessings are upon believers, when he nourishes and preserves them, were it only for this one reason, as proof of his paternal favour.

The next question is similarly existential: Does it follow, conversely, that he who is snatched away from the world before mature age is therefore cursed by God? By no means, Calvin asserts. It rather sometimes happens that the more a man is loved by God the more quickly he is removed from this life (OS I, 105.13-16. Question and answer 190). The next question is directed at God: How does He fulfil his promise in acting like this? Children must know that whatever earthly good God promises, it should be received under this condition: in so far as it is expedient for the good and salvation of our soul. For the arrangement would be absurd indeed if the care of the soul did not always take precedence, he argues (OS I, 105.17.21. Question and answer 191).

The attention then shifts to those who are contumacious to parents (OS I, 105.22-106.2. Question and answer 192). What will become of them? They shall - explicitly stated - not only be punished at the Last Judgement, but here (amid this life) also God will take vengeance on their bodies, either by taking them hence in the middle of their days or by bringing them to an ignominious end, or in other manners. Children are therefore also reprimanded: an inevitable punishment threatens all stubborn and disobedient children.

Is the promise not restricted to the land of Canaan? (OS I, 106.3-7. Question and answer 193). It indeed speaks expressly of that land. Calvin answers that it is true in as far as the Israelites are concerned, but that for them the promise ought to have a wider and more extensive meaning. Because, seeing that the whole earth is the Lord's, whatever be the region we inhabit, He assigns it to us for possession. ${ }^{26}$

The last two questions and answers focus on an aspect of understanding the commandment that Calvin indicated in the $1537 / 1538$ Instruction, that is, that obedience, respect, reverence and service should not only be paid to parents, but to all who are over us - for the same reason, he continues (OS I, 106.8-10. Question and answer 194). What is the reason? That the Lord has raised them to a high degree of honour; for there is no authority whether of parents, or princes, or rulers of any description, no power, no honour, but by the decree of God, because it so pleases him to order the world (OS I, 106.11-15. Question and answer 195).

It is evident that the eleven questions and answers covering the meaning of the fifth commandment echo the structure of Calvin's earlier expositions, particularly as argued in the 1539 Institutio. The set of questions 189-191 obviously mirrors the circumstances and expediency of many povertystricken children living in Geneva and in the region. All traces of conditional obedience, so apparent in the Instruction et Confession as well as the Instutitio are, though, altogether avoided and therefore omitted. Children are also not exposed to Calvin's references to and treatment of the Old Testament's punishment (even the death penalty) of children who transgress the commandment intentionally, although the issue is raised in question and answer 192.

In $1551 L^{\prime} A B C$ François, a concise little handbook to be used in schools, was published in Geneva. Its purpose was not only to teach children the alphabet (and thus reading), but also to educate young learners in the Christian faith. In addition to the Lord's Prayer, the Apostolic Confession and the Ten Commandments, a number of prayers and a short exposition (compiled by Calvin) of what children are expected to know, should they wish to participate in the Lord's Supper, were included. Also added were 21 questions and answers, to be responded to by those children who came forward for questioning in order to be allowed to participate in the Lord's Supper. These questions were also compiled by Calvin. From 1553 it was incorporated in the Genevan Catechism as La maniere d'interroguer les enfans qu'on veut recevoir a la cene Seigneur Iesus Christ (CO 6, 147-160). The questions concerning the Ten Commandments (CO 6, 155ff.) do not offer any explanation or elucidation of their meaning. The focus is instead on the fulfilment of the commands and they are linked in general to soteriological premises significant to a reformed understanding of the redemptive work of Christ.

This concludes the survey of Calvin's exposition of the fifth commandment in published works intended for teaching and instruction.

\section{Conclusion}

It is evident that, when comparing Calvin's explanation of the fifth commandment in his teaching and catechetical 26.Calvin refers to Psalms 24:1, 85:5 and 115:16. 
writings in chronological order, a line of continuity can be discerned. It is consistently constructed around three major threads: the structure of obedience, the promise, and the judgement should the commandment be transgressed. At the same time, an argued expansion of the threads can be detected, as Calvin theologically excavated each of them.

The 1536 Institutio provides us with a concise explanation, guided by the biblical text. According to the will of God, parents should be treated with honour and obedience and be served with gratitude. The Lord promises such children a blessed life on earth, but an inevitable curse should be expected by ungrateful children who neglect to display love and gratitude towards their parents (OS I, 49.21-35). This threefold platform (honour; promise; curse) is maintained in the 1537/38 Instruction et Confession. With regard to honour, Calvin explicitly then added that not only parents, but also those who are in positions of authority, such as princes and magistrates, must be accorded the highest obedience, gratitude and reverence. Honour also indicates a correlation between those honoured and those who revere. Whether parents are worthy to be held in this honour or not, Calvin asserted, makes no difference. They have been set as parents by the Lord, who has willed children to honour them. He gave them as fathers and mothers (Calvin StA $1 / 1,152.22-25)$.

Calvin also mapped out the limits assigned to honouring parents. They are to be obeyed conditionally. If they should demand of children anything that contravenes the commandments of God, or is directed against Him, God should rather be obeyed. Obedience to God is of a higher order than obedience to parents (and authorities), even though He provided them. This obedience must be en Dieu, in God.

The brief Strasbourg l'Institution puerile de la doctrine Chrestienne faicte par maniere de dialogue (OS II, 152-157) does not offer any new trajectories in explaining the fifth commandment. Tutors are added to the list of those who should be obeyed (OS II, 156.41), and no mention is made of any conditions that are to be met in this regard. The Institutio Christianae Religionis, also published in Strasbourg (1539), offered a conclusive and consolidated exposition of the fifth commandment (OS III, 376-378). The ultimate meaning of the commandment is that those whom God in his providence (OS III, 377, 31-32) $)^{27}$ and by his ordinance (OS III, 377.26) ${ }^{28}$ has placed over us, should be respected with honour, reverence, obedience, and gratitude (OS III, 376.30-32). ${ }^{29}$ In so doing, God has established a universal rule (OS III, 377.24-25). ${ }^{30}$ It therefore does

27 ... non tamen sine Dei providentias hunc locum assecuti sunt ... (OS iil, 377, 31-32).

28.... eius ordinatione (OS III,377.26).

29.Summa igitur erit ut quos nobis preafecit Dominus, eos suspiciamus, eosque et honore et obientia et gratitudine honoremus (OS III, 376.30-32). See also tres esse honoris de quo hic loquitur partes, reverentiam, obidientiam, gratitudiam (OS III, 378.2-3).

30.Quapropter ambiguum esse non debet quin hic universalem regulam Dominus statuat ... (OS III, 377.24-25). not make any difference whether superiors are worthy or unworthy of this honour - they have attained their position through God's providence. Calvin now included an elaborative discussion on the punishment of those who abusively and stubbornly violate parental authority (OS III, 377.34) $)^{31}$ to underline the sacredness of this divine ordinance. God thus punishes contempt and abuse (OS III, 377.37-378.4). In Deuteronomy 21:18-21 God, in confirming obedience, decrees the penalty of death for disobedient and rebellious children (OS III, 378.5-7). If, however, parents demand children transgress the law, the children have a perfect right to regard them not as parents, but as strangers. In the same way, Calvin added, children should act towards princes, lords, and every kind of superior (OS III, 379.21-24). ${ }^{32}$

In his teaching on the commandment in the 1539 Institutio, Calvin included a reflection on the 'misuse' and misunderstanding of the promise, as if it guaranteed and presupposed unlimited wealth and prosperity. According to Calvin, the point is that a long life is promised in so far as it is a blessing from God; and that it is a blessing only in so far as it is evidence of God's favour, which he testifies to his servants far more richly and substantially through death, and proves it in reality (OS III, 378.37-379.2).

The remaining publications of Calvin do not contain any new avenues of thought. The Catechismus, though, reflects a contextualised approach: it is notable that the key issue of conditional obedience is omitted. For pedagogical reasons only? However, further research will have to clarify this omission. The Registers of the Consistory of Geneva contain interesting material in this regard. This indicates which of and how the trajectories of Calvin's explication of the commandment were followed and how they were applied in the community. In addition, Calvin's sermons will also shed valuable light on the subject of the reception of his thinking. An in-depth appraisal of contemporary protestant exposition and teaching on the fifth commandment would broaden the horizon of our understanding of Calvin's instruction of the commandment.

Calvin's instruction on (and therefore his interpretation of) the fifth commandment should also be theologicallycritically compared with that of the contemporary Roman Catholic thought and teaching on this commandment. It is, for example, common knowledge that in explaining the (fourth) commandment, The Catechism of the Council of Trente emphatically included the ecclesiastical hierarchy to be honoured (i.e. loved, respected and obeyed). The survey of Calvin's instruction on the fifth commandment indeed exposed new avenues to be pursued in further research on Calvin.

31.Monstra enim sunt, non homines ... (OS Iil, 377.34).

32. Quare si in Legis transgressionem nos instigant, merito tum non parentes nobis habendi sunt, sed extranei, qui nos a veri Patris obedientai subducere conantur (OS III, 379.21-24). 


\section{Acknowledgements}

\section{Competing interests}

The author declares that he has no financial or personal relationship(s) that may have inappropriately influenced him in writing this article.

\section{Bibliography}

Calvin, J., 1863-1900, 'Opera quae Supersunt Omnia', in G. Baum, E. Cunitz \& E. Reuss (eds.), Corpus Reformatorum, Schwetschke, Braunschweig.

Calvin, J., 1926-1962, Joannis Calvini Opera Selecta, vols. I-V (= OS I-V), E.P. Barth, G. (W.) Niesel \& D. Scheuner (eds.), Monachii in Aedibus, Chr. Kaiser, München.
Calvin, J., 1994, Instruction et Confession de Foy dons on use en leglise de Geneve, in E. Busch, A. Heron, C. Link, P. Opitz, E. Saxer \& H. Scholl (eds.), Calvin-
Studienausgabe, Band 1: Reformatorische Anfänge [1533-1541], pp. 138ff. (StA), Studienausgabe, Band 1: Reformatorische Anfange $[1533$
Teilband 1/1, Neukirchener Verlag, Neukirchen-Vluyn.

Calvin, J., 2002, Ioannis Calvini Opera Omnia Denue Recognitae et adnotatione critica Instructa notisque IIlustrata Series III, Scripta Ecclesiastica, Volumen II: Instruction et Confession de Foy dont on use en l'eglise de Geneve; Catechismus se Christianæ religionis Institutio ecclesiæ Genevensis, in A. Zillenbiller (ed.), Droz, Geneve.

CO, see Calvin, J., 1863-1900.

COR, see Calvin, J., 2002.

De Greef, W., 1989, Johannes Calvijn. Zijn werk en geschriften, Uitgeverij Goudriaan, Kampen.

OS, see Calvin, J., 1926-1962.

Saxer, E., 1994, Genfer Katechismus und Glaubensbekenntnis (1737), in E. Busch, A. Heron, C. Link, P. Opitz, E. Saxer \& H. Scholl (eds.), Calvin Studien-Ausgabe Band 1 Reformatorische Anfänge (1533-1541) Teilband 1/1, pp. 131-137, Neukirchener Verlag, Neukirchen.

Selderhuis, H.J. (ed.), 2008, Calvijn Handboek, Uitgeverij Kok, Kampen. 